\title{
Extra-Class Activities to Support the Energy Education of Students of the Transport Operation Specialty
}

\author{
Julio César Ponce de León Guerra*, Mabel del Pilar Espinosa Torres, Miguel Alejandro Riverón Ca- \\ brera
}

Department of Mechanical Engineering, University of Holguín, Holguín, Province of Holguín, Cuba.

\begin{abstract}
How to cite this paper: Julio César Ponce de León Guerra, Mabel del Pilar Espinosa Torres, Miguel Alejandro Riverón Cabrera. (2021). Extra-Class Activities to Support the Energy Education of Students of the Transport Operation Specialty. The Educational Review, USA, 5(11), 410-417.

DOI: 10.26855/er.2021.11.002

Received: October 9, 2021

Accepted: October 31, 2021

Published: November 10, 2021

Corresponding author: Julio César Ponce de León Guerra, Department of Mechanical Engineering, University of Holguín, Holguín, Province of Holguín, Cuba.

Email: jcponce@uho.edu.cu
\end{abstract}

\begin{abstract}
The demand of energy increases every day and constitutes one of the main worries for several fields of the science, especially for environmental issues. The knowledge of energetic sources and how they are used has a great importance for Cuban Education System and particularly for Technical and Professional Education. This article is based on previous studies about this issue and it deals with about some extra-class activities addressing to contribute to energy education in the Technical and Professional Education process of Transport Operation specialty. The extra-class activities were suggested to students from third-years of Transport Operation specialty. For developing this proposal, sequential methods were used. They consist of theoretical methods such as, analysis-synthesis, induction-deduction and empirical methods such as, scientific observation, interviews, surveys document review, and dialogue with specialists, as well as instruments for collecting, processing, analyzing and interpreting the data obtained. As sample, 65 participants were intentionally selected from “Calixto García Iñiguez” Technical School and University of Holguín in Holguín province.
\end{abstract}

\section{Keywords}

Extra-class activities, Transport Operation specialty, Energy education, Renewable energy sources

\section{Introduction}

The current development of society is directly related to energy consumption. Every day, the international community and energy experts observe how fossil fuel reserves decrease. This has been the cause of war conflicts that have as a background the control of these resources. Another element to highlight is how the indiscriminate consumption of these fuels affects the environmental balance, which has brought with it a global warming, the emission of gases that cause the greenhouse effect and acid rains, which have contributed to increase the extreme weather events. Other phenomena derived from the consumption of these resources are soil, water and air pollution.

The generation of electricity, cars and industries, besides the environmental impact generated, are causing the depletion of fossil fuels. These issues have been addressed in different conferences and events at the international level such as: The Intergovernmental Conference of Tbilisi in 1977, The United Nation Conference on Environment and Development (UNCED) that was held in Rio de Janeiro in 1992, The Kyoto Protocol, 1997; The Santo Domingo Declaration 
in 1999; World Summit on Sustainable Development, held in Johannesburg in 2002; Copenhagen Conference in 2009, for naming a few examples.

The accelerated consumption of fuels influenced in the so-called energy crises that appear frequently and affect millions of human beings. These crises involve the world economy and exacerbate social problems such as, hunger, poverty, unhealthiness, etc.

Consequently, it is required the action from all sectors of society in order to achieve a safe and environmentally sustainable energy future. Saving and using new sources of renewable energy is one of the most viable alternatives for the development of society nowadays, without risking the well-being of current and future generations.

Several researchers (Arrastia, 2007; Pérez, 2009; Vázquez, 2010; Domínguez, 2012; Ponce de León, 2014, among others) refer to some actions that could help to mitigate the effects of the problems previously raised, such as: extending the life of non-renewable energy resources, through the use of nuclear energy, saving energy from the manufacture of more efficient equipment and substituting it by less efficient ones, as well as, achieving the transition from fossil energy to new ways of obtaining energy with the application of environmental impact mitigation strategies. However, none of them alone will be able to solve the energy problems, because a systemic endeavor is required with the participation of all sciences branches.

It is clear that sustainable technologies can reduce greenhouse gas emissions and address environmental problems such as air quality and climate change. Opportunity is the greatest in emerging markets, where population growth has triggered dramatic rises in electricity consumption. However, their adoption of energy efficient appliances has been slow and understanding why is limited (Nguyen, N., Greenland, S., Lobo, A., \& Nguyen, H. V., 2019).

In fact, a transition to renewable energies does not merely represent the development of energy generation technology, but instead marks the emergence of new approaches to energy production and consumption, together with similarly novel skill requirements (Malamatenios, 2016). Therefore, solving this problem requires not only the participation of economic and technological factors, but also education is responsible for performing in an effective and creative way to achieve the development of a responsible awareness in citizens.

Regarding the demographics, the enquiries by age follow the same pattern as similar sectors of the economy (i.e., conventional energy) and the high percentage of enquires from women suggests that there is a higher level of interest from women in renewable energy compared with conventional energy (Lucas, H., Pinnington, S., \& Cabeza, L. F., 2018).

Education has a vital role to play in the development of a sustainable society. It is a powerful agent of social change, it raises awareness of new developments, it provides training for the professionals and it trains researchers who will develop the next generation of systems and devices (Jennings, P., 2009, p. 436).

For this reason, energy education must develop a solid foundation in order to help mitigate the negative effects caused by the indiscriminate consumption of fossil fuels. As a resultant, educating current and future generations in order to preserve and protect the natural ecosystem of the planet and energy resources must become a priority task in the educational field.

Referring to this aspect, Castro, J. and Gallego A. (2015) raise the necessity need to reflect and work on the development of proposals on energy education, fundamentally from four approaches: the inevitable dependence of human societies on energy sources; energy saving; the depletion of energy sources and, finally, the consequences on the environment.

Concerning energy education, several studies have been developed, both nationally and internationally, such as: Kandpal, T. and Garg, H. (1999); Dias, R. A., Mattos, C. R., and Balestieri, J. A. P. (2004); Arrastía, M (2007); Pérez, E. (2009); Jennings, P. (2009); Vázquez, J. (2010); Carrico, A. R. and Riemer, M. (2011); Ávila, E. (2012); Morales, C.; Guerra M. Salcedo, Iraola P. (2013); Gallego, A. and Castro, J. (2014); Bosque, R. (2014); Kandpal, T. C. and Broman, L. (2014). Kacan, E. (2015); Zyadin, A. (2015); Castro, J (2016); Noa, S., Martínez, G., and Fabá, B. M. (2018); Domínguez, Z., Inés P., and Morales, D. (2020), among others. These investigations have enriched the theoretical foundations that support the pedagogical and didactic sciences around energy education based on the need to achieve environmental protection and sustainable development.

A review about life cycle assessment (LCA) and research-based teaching in renewable and sustainable energy education was written by Mälkki, H. and Alanne K. (2017) with the purpose of seeking greater understanding of how LCA can be useful in (higher) energy education, particularly as a research-based approach for the assessment of the comprehensive sustainability of renewable energy systems. The findings of that review are discussed in terms of a research-teaching nexus with the aim to identify those learning approaches that enhance students' sustainability competences to act as decision-makers following graduation. To that end, the paper deals with the aforementioned topic of the use of LCA in energy education from two perspectives, namely, analytically surveying, the LCA studies in renewable 
energy and examining the LCA applications in education. An extensive review of LCA studies applicable to renewable and sustainable energy revealed that LCA is widely used in energy research for assessing environmental sustainability and compiling sustainability indicators of the renewable energy systems. Those theoretical foundations were very important to understand some perspective developed in education field.

Regarding energy education at education levels Kandpal, T. C. and Broman, L. (2014) consider that the future well-being of mankind would also depend upon its ability to make judicious use of presently existing non-renewable resources of energy (with due appreciation of inter-generational equity in their consumption and utilization) and to harness new and renewable source of energy. Obviously, the problems involved are both immediate and long range. Since many of the viable solutions would be developed in future, one of the most important responsibilities of the present generation of energy educators is to impart suitable education/training at school level to facilitate appreciation of all the energy related complex issues and also to motivate them to seek proper solutions. Concerted efforts should be made to improve the knowledge and appreciation of school students about renewable energy sources and technologies.

Researchers such as Keramitsoglou, K. M. (2016) focus on devising effective and efficient strategies in educational policy at secondary formal education. This investigation lights on adolescents' knowledge, perceptions and attitudes towards Renewable Energy. Overall, they demonstrated how flexible and equal provision of opportunities for all students to learn about renewable energy sources, enhancement of their understanding of place-based energy policy implementation and cultivation of their critical thinking skills could lead to efficient and effective education policy on renewable energy sources.

In the case of the research addressed by Kacan, E. (2015), it was developed an "Alternative Energy Sources Technology Programme" and it was constructed a dynamic and modern curriculum in order to evaluate the effect of energy related educational programme on renewable energy awareness of students in the vocational-technical education. Also, determining the awareness level of students about the renewable energy sources will be a reference to ascertain the effect of new departments and/or programmes opened within Technical Sciences Vocational Schools.

The authors Rosemary N. Wojuola, Busisiwe P. and Alant (2019) address a research based on a previous study that explored the beliefs, perceptions and attitudes of the Nigerian public to renewable energy technologies so as to derive implications for science and technology policy and education in the country. They applied an analysis of the sources of information about renewable energy technology and revealed that sources of information included radio, television, schools, reading in textbooks and seeing it in the neighbourhood. In terms of the quantitative data, the majority of the sampled people had become aware of renewable energy from television (63.9\%) followed by school (10.5\%), radio (10.2\%), the internet (4.8\%), and conferences $3.1 \%$. The potential knowledge obtained about renewable energy from schools and conferences was surprisingly very little. This also points to the need for effective sustainable energy education in schools.

From the didactical design perspective, Ott, A., Broman, L., and Blum, K. (2018) experience a challenge to utilization of fossil fuel as it makes more meaning to use renewable energy sources and not to pollute the atmosphere. Contemporary development of digital tools implies possibility to control conversion processes for use of energy efficiently.

According with the literature consulted, the treatment of energy content is a necessity for contemporary society. In this sense, Technical and Professional Education has a great potential to contribute to energy education due to its own curricular characteristics. This level of education is aimed at the training of professionals capable of solving the technical problems inherent to their profession and energetic issues play an important role in it.

In technical education and specifically in case of the transport operation specialty, energy education is particularly important. This is because the students of this specialty in their training process must learn how to plan, control and use energy resources. As a result, the main purpose of this article is to specify the proposal of extra-educational activities to favor the energy education of students of the Transport Operation specialty.

\section{Materials and methods}

In the development of this article, the logic is established from the use of theoretical methods, such as: the analysis-synthesis that was used to determine the theoretical foundations that support the proposed extra-class activities, the induction-deduction with the aim of interpreting the data, general and particular results obtained in the research process.

The empirical methods were used for example: scientific observation in order to determine the shortcomings and strengths in the development of energy education of students, from the introduction of the extra-class activities proposed, interviews and surveys that made it possible to specify the main strengths and shortcomings that arise in the development of energy education in the Transport Operation specialty and the review of documents that allowed to establish the theoretical referential framework. 
In addition, dialogue with specialists was used and instruments were applied for the collection, processing, analysis and interpretation of the data obtained. Finally, with the aim of assessing the relevance of the application of the extra-class activities proposal, critical reflection workshops were held.

\section{Results and Discussion}

The educational process includes two parallel processes: the extra-class and the extra-curricular process that are strongly interlinked. These processes are transcendental to complement the teaching-learning process that occurs in the classrooms. Extra-class activities in Technical and Professional Education go beyond the cognitive and include the affective. These activities have a strong educational influence on students.

Regarding extra-class and extra-curricular work, Guillermina Labarrere and Gladys Valdivia (2016) consider that it is exceptionally valuable as a way to unite the school group, which constitutes the core of the organization and development of educational work.

Extra-class activity is that which is carried out outside of teaching hours, organized and directed by the school to achieve educational and instructional objectives (Labarrere, G. \& Valdivia, G., 2016).

The extra-class and extra-curricular activity must be attractive and innovative, they should satisfy individual and collective interests. It will be more educational and emotional as long as they are organized in more interesting way. In order that students attend them with pleasure, no matter if the activity is job training, a meeting or an information activity, the students must be motivated. If the students do not know the content of the activity that they are going to carry out and once in it, the activity is not enjoyable and interesting, they will reject it, their attendance will be formal and the activity will have little influence in favor of the development of their personalities. Keep in mind that monotony breeds formalism, as well as misbehavior (Labarrere, G. \& Valdivia, G., 2016). In addition, these authors add that extra-class and extra-curricular activities must be carried out systematically with the active participation of all students.

In the same way, educational activities must continue outside the classroom and adopt several forms of extra-class and extra-curricular activity, with its own objectives, content and forms of organization.

Extra-class activities, especially organized in the pedagogical process of Technical and Professional Education, provide students with the most diverse ways to satisfy their interests, developing in them positive attitudes towards research, reading and other manifestations of culture and art, hence the possibility of developing activities of this type to contribute to energy education.

Extra-class work is a form of organization of the educational process and constitutes one of the greatest achievements of pedagogy. These activities are implemented inside and outside the school, directed by teachers, instructors or specialists. The extra-class activities proposed were developed based on the following criteria:

- The development of skills.

- Social relationships.

- Use of free time.

- $\quad$ Promote the professional training of students.

- Promote energy and environmental education.

For the devising these activities, the following structure is proposed:

- $\quad$ Title: to name the activity.

- $\quad$ Objective: to express the intention or the purpose of the activity.

- Teaching methods: to contribute to the activity regulation of the teacher and students, depending on the achievement of the objectives.

- Description: to describe the extra-class activity (what it consists of and how it should be carried out).

- Learning situation: guides students what to do.

- $\quad$ Place: where the activity is planned to develop.

Next, seven extra-class activities are proposed to be developed by the students. Contents related to energy sources used in Transportation are intentionally applied.

\section{Activity 1: Devising of bulletin board}

Title: Renewable energy sources

Objective: To disseminate the general contents of renewable energies, contributing to environmental awareness in favor of the adequate manage of natural resources.

Teaching methods: bulletin board method.

Description: A group of students is selected and they are guided to carry out a search for information related to re- 
newable energy sources and their application in the transportation field. The bulletin board will be designed with the following structure:

Types of renewable energy sources

News

Curiosities

Novelties

Images

Others that should be interesting to students

Learning situation: To create an informative bulletin board in which news, curiosities, Novelties, images and any other element of interest related to renewable energy sources are exposed.

Place: Technical school

\section{Activity 2: Leaflet}

Title: The aware use of energy.

Objective: To spread fuel and lubricant saving actions, contributing to aware use of energy.

Teaching methods: Cooperative method

Description: Some students of the Transport Operation specialty are selected to work in teams and they are guided to prepare a leaflet in which the information regarding the saving of fuels and lubricants is disseminated so that it can be used both, in technical schools and in the production and service companies, then a workshop will be developed in which the best leaflet will be selected, which will be awarded, printed and spread in the technical school and the production companies in which the pre-professional practices are developed.

Learning situation: Prepare a leaflet containing information on saving fuel and lubricants that can be used both in the technical school and in production and service companies.

Place: Technical school

\section{Activity 3: Specialized Lecture}

Title: Current and future trends in the application of renewable energy sources.

Objective: To analyze current and future trends in the application of renewable energy sources, promoting the need for the efficient use of fossil fuels.

Teaching methods: Expository

Description: A specialist on the subject of the production company where the student carries out their training is invited to develop a lecture about current and future trends in the application of renewable energy sources, both internationally and nationally.

Learning situation: Some questions are directed to the students to guide the lecture.

1- When does the human race start to use energy sources?

2- How have energy sources been evolved to date?

3- Are fossil fuels inexhaustible? Argue.

4- What is the current trend in the use of renewable energies?

5 - Do you think it is necessary to change the energy matrix in our country?

6- How do you think renewable energy sources will be used in the future?

Place: Specialized Transportation classroom.

\section{Activity 4: Visit to production enterprise}

Title: Energy sources in the transport production process.

Objective: To characterize the application of energy sources in the transport production process, as well as their impact on the environment.

Teaching methods: observation

Description: To coordinate a visit to transport enterprise in the Holguín province. Visits are made to the workshops of these centers with third-years students of the Transport Operation specialty. An observation guide is developed with the aim of guiding students in order to detect and inquire about its strengths and weaknesses in the application of energy sources and their impact on the environment.

Learning situation: Prepare a presentation that summarizes the results of the observation guide carried out and sug- 
gests some measures that according to your criteria are necessary to contribute to the saving and rational use of energy resources and the care of the environment.

Observation Guide

1) What types of fuels are used in the production or service process?

2) How is the operation of fuels planned?

3) What security measures are used in the transportation and storage of fuels?

4) What worker protection standards and hygiene in the workplace are used for handling of fuels?

5) How was organize the fire protection equipment available in the workshop?

6) What problems related to energy issues did you observe during the visit?

7) Explain how you could contribute to improve the use of energy.

Place: enterprise

Activity 5: Contest

Title: Renewable energies and sustainable development.

Objective: To promote information, reflection and debate about the use of renewable energy sources for sustainable development in students, workers and researchers of the technical school and the community.

Teaching methods: Investigative.

Description

Students are encouraged to participate in the contest, the announcement of which is shown below.

Announcement for the contest: Renewable energies and sustainable development.

The Department of Transportation of "Calixto García Iñiguez" Technical School and the Department of Mechanical Engineering of University of Holguín announce the Renewable Energies and Sustainable Development contest.

Students, workers and researchers interested in the topics to be addressed will be able to participate.

The topic of the contest will focus on the following thematic lines:

Renewable and non-renewable energy sources

Renewable energy sources and care for the environment

Renewable energies, savings and economic development

Transportation and renewable energy sources

It will be possible to compete in different modalities: essay, testimony, story, painting, engraving and photography.

Two prizes and two mentions will be awarded and the results will be announced at the Student Scientific Conference of Mechanical Engineering major at the University of Holguín.

Learning situation: Transport Operation students are encouraged to participate in the contest, for which they must select at least one of the modalities established by the contest.

Place: “Calixto García Iñiguez” Technical School

Activity 6: Presentation of a book

Title: Presentation of the Book: "Energy Revolution a challenge for development” by the author Gilberto Norberto Ayes Ametller.

Objective: To promote the reading of materials related to renewable energy issues.

Teaching methods: Expository

Description: The book is presented: "Energy Revolution a challenge for development" by the author Gilberto Norberto Ayes Ametller, of which a brief introduction is made to his scientific and research performance in the area of energy education.

Among other aspects, the book addresses: What is the energy revolution? How is it expressed? What does the energy revolution mean for sustainable development? And what is the challenge of it?

Learning situation: Participate in the presentation of the book "Energy Revolution a challenge for development” by 
the author Gilberto Norberto Ayes Ametller.

Ayes Ametller, G. N. (2008) “Energy Revolution: a challenge for development”. Havana city, Scientific-Technical press.

Place: The library of the Technical School

Activity 7: Video debate

Title: Cuba and fuel savings with the use of electric vehicles.

Objective: To discuss the video related to the application of renewable energies in electric vehicles imported in Cuba, contributing to the energy training of students.

Teaching Methods: Discussion

Description: To carry out this activity, an observation guide is prepared in order to facilitate the subsequent debate of the video. It is coordinated with the video room for the projection of the material.

Learning situation: Watch the following video and respond to the guide that we offer you below:

1) What company do these vehicles belong to?

2) What advantages do these vehicles have in respect to other in the company?

3) What type of energy does the vehicle use?

4) What other projects does the company have to reduce energy consumption expenses?

5) How many years does the company require to recover the investment of these vehicles?

6) Do you consider that this type of technology can replace internal combustion vehicles. Why?

Place: Community video room.

Video: Information System of Cuban Television (2019) Cuba: fuel savings with the use of electric vehicles. Recovered from https://www.youtube.com/watch?v=WvnbANpCCLU

\section{Conclusion}

Energy education responds to the need to contribute to comprehensive training of technician students in the specialty of Transport Operation and contributes to the formation of responsible attitudes and the appropriation of values of respect for the environment, hence the importance of the topic.

Energy education requires the students training in the Transportation Operations specialty, so that basic scientific and research knowledge is applied for its development.

The development of extra-class activities contributes to training, use of free time and motivation of the students in the development of energetic awareness.

\section{References}

Arrastia, M. (2007). Energy education of environmental respect premises for sustainable development: Energy Education and sustainable development. Santiago de Compostela, Spain.

Ávila, E. (2012). Appropriation process: a distinctive feature in energy education. Holguín Sciences vol. XVIII, 2, (2012) https://www.redalyc.org/pdf/1815/181524305009.pdf.

Bosque, R. (2014). The environmental and energy education state of art in Universities of Pedagogical Sciences of Cuba. Varona Journal, 58, (2014), pp. 67-77. https://www.redalyc.org/pdf/3606/360634165008.pdf.

Carrico, A. R. and Riemer, M. (2011). Motivating energy conservation in the workplace: An evaluation of the use of group-level feedback and peer education. Journal of Environmental Psychology, 31(1), 1-13. doi:10.1016/j.jenvp.2010.11.004.

Castro, J. (2016). Research about teaching-learning process of the energy issues since the beginning of energy education. Scientific Journal, 26. Bogotá, D. C. https://revistas.udistrital.edu.co/index.php/revcie/article/view/16232/15583.

Castro, J. and Gallego, A. (2015). Energy education: a priority for the millennium. Scientific Journal, 21, 111-120. doi: 10.14483/udistrital.jour.RC.2015.21.a11.

Dias, R. A., Mattos, C. R., and Balestieri, J. A. P. (2004). Energy education: breaking up the rational energy use barriers. Energy Policy, 32(11), 1339-1347. doi:10.1016/S0301-4215(03)00100-9.

Domínguez, Z. (2012). Energy education of the students of Mathematics-Physics Bachelors in Education major. Ph.D. Thesis, Holguín: University of Holguín.

Domínguez, Z., Inés, P., and Morales, D. (2020). Energy education favored from the explosive valuation method. Ibero-American Environment \& Sustentabilidad Journal. 3(1), 82-91. doi:org/10.46380/rias.v3i1.76. 
Dos Santos, C. and León, V. (2011). Energy education: contributions from the teaching-learning process of Physics in Senior High School Education. 34/5000 https://www.eumed.net/rev/tlatemoani/07/vdlh.pdf.

Gallego, A., Castro, J., and Rocha, P. (2016). The need for an energy education from the sustainability sciences. Tecné, Episteme $y$ Didaxis: TED. Bogotá. https://revistas.pedagogica.edu.co/index.php/TED/article/view/4735/3875.

Gallego, A. and Castro, J. (2014). Energy education: a new research topic in engineering. En: Ingeniería, Vol. 19, (2), 147-163. https://revistas.udistrital.edu.co/index.php/reving/article/view/7595/9719.

Information System of Cuban Television. (2019). Cuba: fuel savings with the use of electric vehicles. https://www.youtube. $\mathrm{com} /$ watch?v=WvnbANpCCLU.

Jennings, P. (2009). New directions in renewable energy education. Renewable Energy, 34(2), 435-439. doi:10.1016/j.renene.2008.05.00.

Kacan, E. (2015). Renewable energy awareness in vocational and technical education. Renewable Energy, 76, $126-134$. doi:org/10.1016/j.renene.2014.11.013.

Kandpal, T. and Garg, H. (1999). Energy education. Applied Energy, 64(1-4), 71-78. PII: S0306-2619(99)00076-8.

Kandpal, T. C. and Broman, L. (2014). Renewable energy education: A global status review. Renewable and Sustainable Energy Reviews, 34, 300-324. doi: http://dx.doi.org/10.1016/j.rser.2014.02.039.

Keramitsoglou, K. M. (2016). Exploring adolescents’ knowledge, perceptions and attitudes towards Renewable Energy Sources: A colour choice approach. Renewable and Sustainable Energy Reviews, 59, 1159-1169. doi:10.1016/j.rser.2015.12.04.

Labarrere, G. and G. Valdivia. (2016). Pedagogy. Caribean Editions, Santiago de Cuba. Cuba.

Lucas, H., Pinnington, S., and Cabeza, L. F. (2018). Education and training gaps in the renewable energy sector. Solar Energy, 173, 449-455. doi:10.1016/j.solener.2018.07.061.

Malamatenios, C. (2016). Renewable energy sources: jobs created, skills required (and identified gaps), education and training. Renew. Energy Environ. Sustain., 1, 23. doi: org/10.1051/rees/2016038.

Mälkki, H. and Alanne, K. (2017). An overview of life cycle assessment (LCA) and research-based teaching in renewable and sustainable energy education, Renewable and Sustainable Energy Reviews, Volume 69, 2017, pp. $218-231$. https://doi.org/10.1016/j.rser.2016.11.176.

Morales, C., Guerra, M. Salcedo, and Iraola, P. (2013). Strategy for professional training in energy education for high-school teachers. REFCalE. Publicación arbitrada cuatrimestral, Vol. 1, Año 2013, No. 1 (Enero-Abril) Recuperado de: http://refcale.uleam.edu.ec/index.php/refcale/article/view/29/27.

Nguyen, N., Greenland, S., Lobo, A., and Nguyen, H. V. (2019). Demographics of sustainable technology consumption in an emerging market: the significance of education to energy efficient appliance adoption. Social Responsibility Journal, vol. 15. (6): 803-818. doi:10.1108/srj-11-2018-0312.

Noa, S., Martínez, G., and Fabá, B. M. (2018). Power-saving education in junior high school. An alternative for its development. Transformación, 14(3): 360-370. http://scielo.sld.cu/pdf/trf/v14n3/2077-2955-trf-14-03-360.pdf.

Ott, A., Broman, L., and Blum, K. (2018). A pedagogical approach to solar energy education. Solar Energy, 173, 740-743. doi:10.1016/j.solener.2018.07.060.

Pérez, E. (2009). Professional improvement for energy education of the professors of Teachers Training Collages. Ph.D. Thesis, Holguín. University of Holguín.

Ponce de León, J. (2014). Renewable energies in the permanent training of the education professionals in Mechanization career. Spc. Thesis, Holguín, University of Holguín.

Rosemary, N., Wojuola, Busisiwe, P., and Alant. (2019). Sustainable development and energy education in Nigeria. Renewable Energy, 139(2019), 1366-1374. https://doi.org/10.1016/j.renene.2019.03.010.

Vázquez, J. (2010). Theoretical Model for Energy Education. Varona, Scientific-Methodological Journal, 51, pp. 44-49, La Habana, Cuba. https://www.redalyc.org/pdf/3606/360635569007.pdf.

Zyadin, A. (2015). Prospects for renewable energy education (REE) in elevating youth energy and environmental awareness in Jordan Dissertation Forestalls, 207, p. 39. http://dx.doi.org/10.14214/df.207. 